\title{
Protective Effect of Terminalia Chebula Extract on Serum Total Protein against
}

\section{Paracetamol Induced Liver Damage in Wister Albino Rats}

${ }^{*}$ Yeasmin $T^{1}$, Akhter $Q S^{2}$, Imtiaz $M^{3}$, Noor $N^{4}$, Khanam $A^{5}$,

\begin{abstract}
Terminalia Chebula extract is used for regeneration of hepatic cells and protection of liver against damage due to its active component. This study aims to observe the protective effect of Terminalia Chebula against Paracetamol induced change of serum total protein level in Wister Albino rats. The study was carried out in the Department of Physiology, Dhaka Medical College (DMC) during January 2013 to December 2013. A total number of 44 rats, age ranging from 90 to 120 days, weight between 150 to $200 \mathrm{gm}$ (initial body weight) were selected for the study. After acclimatization for 14 days, they were divided into control groups and experimental groups. Before sacrifice, final body weights of all the rats were measured. Then all the rats were sacrificed on 22nd day and then blood samples were collected. For assessment of liver function, serum total protein level was done by using standard laboratory kits. The mean serum total protein level was significantly $(p<0.001)$ lower in paracetamol treated control group in comparison to those of baseline control group. Serum total protein level of all experimental groups were significantly $(P<0.001)$ higher than Paracetamol treated control group. From the results of this study, it may be concluded that Terminalia Chebula may have some protective effect against Paracetamol induced liver damage in rats.
\end{abstract}

Keywords: Terminalia chebula, Hepatoprotective, Paracetamol, Protein.

1, *Tania Yeasmin, Assistant Professor, Department of Physiology, TMSS Medical College, Bogra. Email: bappy04@hotmail.com

2, kazi Shamima Akhter, professor \& Head, Department of Physiology, Dhaka Medical College, Dhaka.

3, Masud Imtiaz, Associate professor, Department of Physiology, Khulna City Medical College, Khulna.

* Corresponding Author

\section{INTRODUCTION:}

Liver is an important organ which plays a vital role in regulating homeostasis within the body by various functions. 1 Liver injury or diseases caused by virus, toxic chemicals, environmental pollutants, certain drugs that has been increase for the past few decades. 2 Liver diseases are most serious health problem worldwide, with high endemicity in developing countries. About 20,000 deaths occur every year due to liver diseases. 3 According to world health organization (WHO) more than $80 \%$ of the world's populations rely on modern medicines for their primary health care needs4.The modern or synthetic drugs used in the treatment of liver diseases have been reported to cause serious adverse side effects. It has been reported that alternative natural sources of medicinal plants have less or no side effect. 5

Paracetamol (Acetaminophen) is an analgesic and antipyretic drug which is widely used to cure headache, fever, and other pains and is readily available without prescription. Increasing use and easy availability of paracetamol have led to misuse of the drug and may cause a number of serious clinical problems.6 Paracetamol is hepatotoxic when used in excessive doses or when used in therapeutic doses for a prolonged period.7, 8 In medicinal practices, reliable liver protective drugs are not available but herbal plants may play an important role in management of liver disorders. 9

Terminalia chebula has been used in herbal medicine throughout the ancient times in Bangladesh because it is cultivated in many places of Bangladesh. Locally it is called as Haritaki (Combretaceae family). It is also called the king of medicine because it has been widely used in ayurveda, unani, siddha and homeopathy.10 It contains tannin, chebulic acid, glycosides, sugar, triterpenoids, steroids and flavonoids. Due to some active components of terminalia chebula has high medicinal value. Many studies have been reported for biological properties and protective effects of Terminalia chebula on different diseases.11 Different researchers from different countries have been studied the hepatoprotective effects of Terminalia chebula.12 Recently, some investigators observed that Terminalia chebula significantly increased the paracetamol induced elevation of serum total protein in rats.13,14 From the medicinal values, the present study has been designed to investigate the 
protective effect of Terminalia chebula on paracetamol induced liver damage in Wister albino rats.

\section{METHODS:}

This experimental study was conducted from January' 13 to December'13 in the Department of Physiology, Dhaka medical college (DMC), Dhaka. A total number of 44 apparently healthy Wister albino rats, weight between 150 to 200 grams; age ranging from 90 to 120 days was used. The rats were purchased from the animal house of Department of Pharmacy, Jahangir Nagar University, Shavar, Dhaka. The protocol of this study was approved by Institutional Ethics Committee (IEC) of Dhaka Medical College. The rats were kept in metallic case in the animal house of Institute of Nutrition and Food Science, University of Dhaka (DU). Prior conducting the study, rats were kept in a standard laboratory condition on a 12/12 hour light/dark cycle for 14 days acclimatization. All the rats received basal diet for 21 days. Total study period was 35 consecutive days and the work was done in the Institute of Nutrition and Food Science, DU. After selection, all the rats were acclimatized for 14 days. Then the rats were studied for 21 consecutive days. After acclimatization for 14 days, rats were divided into control groups $(\mathrm{n}=22)$ and experimental groups $(\mathrm{n}=22)$. Control groups again subdivided into $\mathrm{BC}$ (base line control group, $\mathrm{n}=11$ ) and PC (paracetamol treated control group, $\mathrm{n}=11$ ). Experimental groups were again subdivided in to TCP-PCT (Terminalia chebula pretreated and paracetamol treated group, $\mathrm{n}=11$ ) and PCP-TCT (paracetamol pretreated and Terminalia chebula treated group, $\mathrm{n}=11$ ). After grouping, initial body weight of all the rats were measured on 1st day. All groups of rats received basal diet for 21 consecutive days. In addition to basal diet on $21 \mathrm{st}$ day, BC received propylene glycol $(2 \mathrm{ml} / \mathrm{kg}$ body weight, orally) and PC received single dose of paracetamol suspension $(750 \mathrm{mg} / \mathrm{kg}$ body weight, orally). In experimental groups, TCP-PCT received Terminalia chebula extract ( $200 \mathrm{mg} / \mathrm{kg}$ body weight, orally) for 21 consecutive days and paracetamol suspension $(750 \mathrm{mg} / \mathrm{kg}$ body weight, orally) on 21st day. Moreover, PCP-TCT received paracetamol suspension $(750 \mathrm{mg} / \mathrm{kg}$ body weight, orally) on the $1 \mathrm{st}$ day and Terminalia chebula extract $(200 \mathrm{mg} / \mathrm{kg}$ body weight orally) for 21 consecutive days.

Powder form paracetamol was purchased from Square pharmaceuticals and $1 \mathrm{gm}$ of paracetamol was dissolved in 9 $\mathrm{ml}$ of propylene glycol and form paracetamol suspension. Again, $300 \mathrm{gm}$ Terminalia chebula mixed with $800 \mathrm{ml}$ distilled water for 3 days and form Terminalia chebula extract which stored in freeze at around $40 \mathrm{C}$ and was fed to the experimental rats. Before sacrifice, final body weights of all the rats were measured. On the 22nd day, all the rats were anaesthetized with the help of chloroform $(30 \%)$ and then sacrificed. The blood samples (approximately $5 \mathrm{ml}$ ) were collected from the heart direct puncturing by using sterile disposable syringes and taken in separate clean and dry test tubes with proper identification numbers. Then blood was centrifuged at a rate of $4000 \mathrm{rpm}$ for 5 minutes. After that the supernatant serum was separated from the blood, collected in a labeled eppendorf and preserved in a refrigerator at $-20^{\circ} \mathrm{C}$ until analytical measurement of serum for total protein in Department of Pathology, Dhaka Medical College. Data was reported in Mean and SD (Standard deviation). Statistical analysis was done by One-way ANOVA test and Bonferroni test.

\section{RESULTS:}

The initial, final and percent $(\%)$ changes of body weight of all rats were almost similar and showed no statistically significant difference between BC vs PC, PC vs TCP-PCT, TCP-PCT vs PCP-TCT (Table I).

Table I: Initial, final and Percent (\%) change of body weight in different groups of rats $(n=44)$

\begin{tabular}{lcccc}
\hline Parameters & $\begin{array}{c}\text { BC } \\
(\mathrm{n}=11)\end{array}$ & $\begin{array}{c}\text { PC } \\
(\mathrm{n}=11)\end{array}$ & $\begin{array}{c}\text { TCP-PCT } \\
(\mathrm{n}=11)\end{array}$ & $\begin{array}{c}\text { PCP-TCT } \\
(\mathrm{n}=11)\end{array}$ \\
\hline Initial body wt(g) Day-1 & $158.18 \pm 6.03$ & $156.45 \pm 6.35$ & $161.18 \pm 14.37$ & $157.91 \pm 9.85$ \\
Final body wt(g) Day-22 & $163.55 \pm 5.96$ & $160.82 \pm 8.52$ & $164.45 \pm 14.69$ & $160.82 \pm 8.52$ \\
\% change from final (F) & & & $2.02 \pm 1.25$ & $1.84 \pm 2.21$ \\
$\begin{array}{l}\text { weight to initial (I) weight } \\
\text { [F-I/I×100] }\end{array}$ & $3.39 \pm 1.26$ & $2.80 \pm 1.8$ & & \\
\hline
\end{tabular}

Table- $\mathrm{I}$ shows the values are Means \pm SD. Statistical analysis was done by one way ANOVA test. $\mathrm{n}=$ Number of rats. $\mathrm{BC}=$ Baseline control group PC = Paracetamol treated control group TCP-PCT $=$ Terminalia chebula pretreated and paracetamol treated group PCP-TCT $=$ Paracetamol pretreated and Terminalia chebula treated group. 
Table I: Initial, final and Percent (\%) change of body weight in different groups of rats $(n=44)$

\begin{tabular}{lcccc}
\hline Parameters & BC & PC & TCP-PCT \\
$(\mathrm{n}=11)$ & $(\mathrm{n}=11)$ & $\begin{array}{c}\text { PCP-TCT } \\
(\mathrm{n}=11)\end{array}$ & \\
\hline Total protein $(\mathrm{mg} / \mathrm{L})$ & $62.36 \pm 3.44$ & $52.00 \pm 2.68^{* * *}$ & $63.64 \pm 6.98 ¥ ¥ ¥$ & $65.00 \pm 7.63 \mathbf{9 g 9}$ \\
\hline
\end{tabular}

Table- II shows the mean serum total protein level was significantly $(\mathrm{p}<0.001)$ lower in PC in comparison to that of BC. But this level was significantly $(\mathrm{p}<0.001)$ higher in TCP-PCT and PCP-TCT in comparison to that of PC. Again there was no significant difference in this level between TCP-PCT and PCP-TCT Table II.

Values are Means \pm SD. Statistical analysis was done by one way ANOVA test and then Bonferroni test. Serum bilirubin $\left({ }^{* * *} \mathrm{p}<0.001 \mathrm{PC}\right.$ vs BC $)(¥ ¥ ¥ \mathrm{p}<0.001$ TCP-PCT vs PC) ( $999 \mathrm{p}<0.001$ PCP-TCT vs PC). $\mathrm{n}=$ Number of rats BC= Baseline control group $\mathrm{PC}=$ Paracetamol treated control group TCP-PCT $=$ Terminalia chebula pretreated and paracetamol treated group PCP-TCT = Paracetamol pretreated and Terminalia chebula treated group.

Figure 1: Mean serum total protein in different groups of rats $(n=44)$

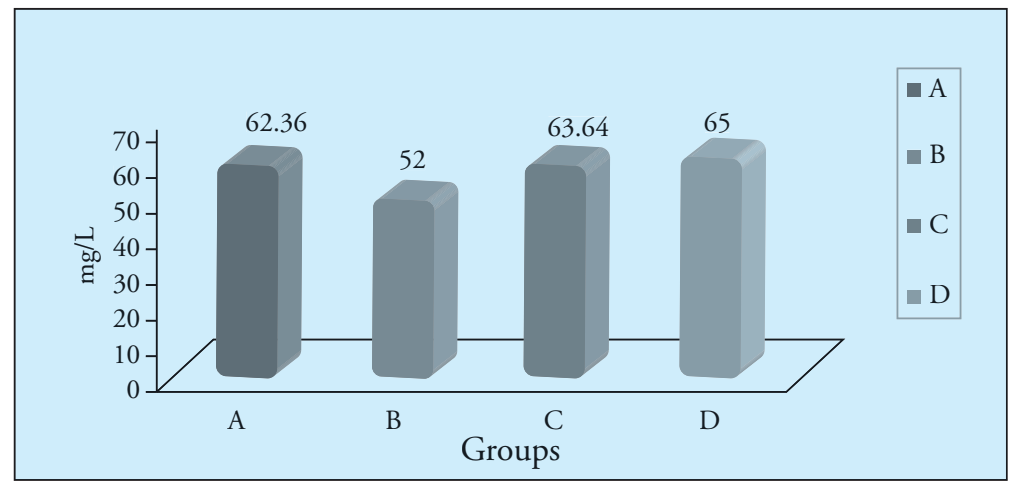

$\mathrm{n}=$ Number of rats

Control group: Without Terminalia chebulaGroup A: BC; Group B: PC

Experimental group: With Terminalia chebulaGroup C: TCP-PCT; Group D: PCP-TCT

\section{DISCUSSION:}

In the present study, serum total protein level was significantly lower in $\mathrm{PC}$ in comparison to that of $\mathrm{BC}$, TCP-PCT and PCP-TCT which is comparable to others15, 16, 17 But no significant change was observed by some researchers18. Different studies reported the toxic effect of high dose of paracetamol on hepatocytes and liver functions. It has been suggested that high doses of paracetamol inhibit the synthesis of RNA and protein which finally leads to necrosis of liver cell19.

It has also been suggested that metabolism of excess paracetamol in liver by conjugation with sulphate and glucuronide causes formation of toxic metabolites such as N-acetyl-p-benzoquineimine (NAPQI). This NAPQI imposes oxidative stress by increasing the formation of reactive oxygen species which causes lipid peroxidation and depletion of antioxidant enzymes. This increased oxidative stress leads to destruction of structural and functional organization of cell membrane causing liver cell damage 20 . In this study decreased level of serum total protein is suggestive of liver cell damage.
Studies on medicinal plants demonstrated that Terminalia chebula contains some active compounds such as vitamin C, ellagic acid, gallic acid, chebulic acid, bellericanin, $\beta$-sitosterol and flavanoids which increase the activities of antioxidant enzymes which in turn obviously protect liver for oxidative damage21. Again Desai et al. noted that Terminalia chebula stimulate protein synthesis, which accelerates the regeneration and production of liver cells thereby contributes hepatoprotective activity11. In this present study, increase level of serum total protein level in TCP-PCT and PCP-TCT rats suggest that supplementation of Terminalia chebula extract provide protection against paracetamol induced liver injury due to its higher content of active component.

\section{CONCLUSION:}

From this study, it can be concluded that Terminalia chebula may have some protective effect with increase serum total protein level against paracetamol induced liver damage. Therefore, increasing serum total protein level due to active components of Terminalia chebula. 


\section{REFERENCES:}

1. Ahsan MR, Islam KM, Bulbul IJ. Hepatoprotective activity of methanol extract of some medicinal plants against carbon tetrachloride-induced hepatotoxicity in rats. Eur J Sci Res. 2009;37(2):302-10.

2. Naglaa H, Hassanen M, Mona H, Ahmed M. Protective effect of fish oil and virgin olive oil on Diethylnitrosamine Toxicity in rats. Int J Nutr food Sci. 2015;4(3):388-96.

3. Kshirsagar AD, Mohite R, Aggrawal AS, Suralkar UR. Hepatoprotective medicinal plants of ayurveda. Asian J Pharm Clin Res. 2011;4(3):1-8.

4. Qadrie ZL, Rajkapoor B, Kavimani S. Hepatoprotective medicinal herbs and animal models for their screening. IJPSR. 2015;6(12):5006-28.

5. Mohammed A, Abubakar SA. Potency of aqueous extract of Azadirachta indica a. juss against lipid peroxidation and liver damage in rats. Int $\mathrm{J}$ Mod Biochemistry. 2012;1(1):27-35.

6. Grieco A, Miele L, ForgioneA, Ragazzoni E, Vecchio FM, Gasbarrini G. Mild hepatitis at recommended doses of acetaminophen in patients with evidence of constitutionally enhanced cytochrome P450 system activity. J Clin Pharm Ther. 2008;33:315-20.

7. Rumack BH, Peterson RC, Koch GG, Amara IA. Acetaminophen overdose: 662 cases with evaluation of oral acetylcysteine treatment. Arch Intern Med. 1981;141(3):380-5.

8. Smilstein MJ, Knapp GL, Kulig RW, Rumack BH. Efficacy of oral $\mathrm{N}$-acetylcysteine in the treatment of acetaminophen overdose. N Engl J Med. 1988;319:1557-62.

9. Kumar V, Sharma A, Machawal L, Khan AA. Beneficial roll of herbal hepatoprotectants: A novel approach to prevent hepatotoxicity due to antituberculosis treatment. J Biomed Pharm Res. 2013;2(3):181-s93.

10. Mahesh R, Bhuvana S, Begum VM. Effect of Terminalia chebula aqueous extract on oxidative stress and antioxidant status in the liver and kidney of young and aged rats. Cell Biochem Funct. 2009;27:358-63.

11. Gupta PC. Biological and pharmacological properties of Terminalia chebula Retz (Haritaki). Int J Pharm Pharm Sci. 2012;4:62-8.

12. Desai S, Gite M, Ahmed A, More Y, Gavitre B, Gawali $\mathrm{V}$. Hepatoprotective and antioxidant activity evaluation of PHF08 on carbon tetrachloride induced hepatotoxicity. Der Pharmacia Lett. 2010;2(1):475-81.
13. Sivachandran S, Hariharan P. Hepatoprotective effect of Terminalia chebula on gentamicine induced toxicity in rats. Inter J Vet Sci. 2012;1(1):31-3.

14. Sharma A, Rathore HS. Prevention of acetaminophen induced hepatorenal toxicity in mice with fruits of Terminalia chebula (Myrobalan). Thai J Toxicol. 2010;25(2):144-53.

15. Sandhyak D, Bhaskhar BG, Mahesh GS, Ahmed A. Evaluation of hepatoprotective activity of a polyherbal formulation (PHF-A) by using galactosamine-induced hepatotoxicity in rats. JPBMS. 2010;1(2):1-5.

16. Doorika P, Ananthi T. Antioxidant and hepatoprotective properties of Terminalia arjuna bark on isoniazid induced toxicity in Albino rats. Asian J Pharm Tech. 2012;2(1):15-8.

17. Elamparithi D, Boominathan M. Comparative study on antimicrobial, hepatoprotective activity of Terminalia chebula different fraction. Int Stand Serial Number. 2012;2(4):16-23.

18. Panunto W, Jaijoy K, Lerdvuthisopon $\mathrm{N}$, Lertprasertsuke N, Jiruntanat N, Soonthornchareonnon N, Sireeratawong S. Acute and chronic toxicity studies of the water extract from dried fruits Terminalia chebula Rezt. in rats. Int J Appl Res Natural Prod. 2011;3(4):36-43.

19. Kon K, Kim JS, Jaeschke H, Lemasters JJ. Mitochondrial permeability transition in acetaminophen-induced necrosis and apoptosis of cultured mouse hepatocytes.J Hepatol. 2004;40:1170-9.

20. Hinson JA, Bucci AR, Irwin LK, Michael SL and Mayeux PR. Effect of inhibitors of nitric oxide synthase on acetaminophen induced hepatotoxicity in mice. Nitric Oxide. 2002;6:160-7.

21. Rasool MK, Sabina EP, Lavanya K, Nithya P. Therapeutic effect of Indian ayurvedic herbal formulation Triphala on acetaminophen-induced hepatotoxicity in mice. J Pharmacol Toxicol. 2007;2(8):725-31. 